\title{
An in vitro metronidazole susceptibility test for trichomoniasis using the InPouch TV $^{\mathrm{TM}}$ test
}

\author{
K A Borchardt, Z Li, M Z Zhang, H Shing
}

Objective: An efficient anaerobic culture system, the InPouch TV ${ }^{\mathrm{rM}}$ test, was used to determine the susceptibility of Trichomonas vaginalis to metronidazole. Glacial acetic acid was employed as a solvent for metronidazole.

Methods: $T$ vaginalis isolates were cultured from 16 symptomatic female patients. The 11 who responded to oral metronidazole, $250 \mathrm{mg}$ tid for 7 days, were considered as having sensitive trichomonads; the 5 who remained infected after treatment were considered to have resistant organisms. All isolates were cultured for minimum lethal concentrations (MLC). Metronidazole was added to a series of pouches; two-fold dilution of the most concentrated was $50 \mu \mathrm{g} / \mathrm{ml}$ and the least was $0.4 \mu \mathrm{g} / \mathrm{ml}$. The inoculum of viable trichomonads was $1 \times 105 / \mathrm{ml}$ in each pouch. Pouches were incubated at $37^{\circ} \mathrm{C}$ for $48 \mathrm{~h}$, examined microscopically for motile trichomonads, and then $0.5 \mathrm{ml}$ was subcultured to drug free pouches. After 5 days incubation at $37^{\circ} \mathrm{C}$, each subculture and culture were examined microscopically for viable trichomonads.

Results: Eleven isolates of $T$ vaginalis from patients responding to metronidazole treatment had MLC between 0.4 to $3.1 \mu \mathrm{g} / \mathrm{ml}$. The MLC from the 5 treatment failure patients were between $12 \cdot 5$ to $50 \mu \mathrm{g} / \mathrm{ml}$.

Conclusions: For the 16 patients in this study, the MLC values determined with the InPouch $\mathrm{TV}^{\mathrm{TM}}$ test differentiated between infection caused by metronidazole sensitive and resistant trichomonads. The mean MLC of clinically resistant isolates was approximately eleven fold higher than the mean MLC of clinically sensitive isolates $(15 \mu \mathrm{g} / \mathrm{ml}$ vs $1.32 \mu \mathrm{g} / \mathrm{ml})$. There was a significant difference between clinically resistant and sensitive isolates $(t=5.47, \mathrm{p}<0.0005)$. This study suggests that the InPouch TV ${ }^{\mathrm{TM}}$ test could be used for distinguishing between metronidazole resistant and sensitive isolates.

(Genitourin Med 1996;72:132-135)

Keywords: trichomonas vaginalis; metronidazole; InPouch TV

\section{Introduction}

Metronidazole (flagyl; 1-hydroxyethyl-2-methyl5-nitroimidazole) is the most effective drug for treating a Trichomonas vaginalis infection. The first evaluation of its clinical efficacy began in France in $1958 .^{1}$ Presently it is the only nitroimidazole available for treatment in the United States. ${ }^{2}$ Prescribed treatment for trichomoniasis is either one $250 \mathrm{mg}$ tablet taken orally 3 times per day for 7 consecutive days, or a single $2 \mathrm{~g}$ dose. ${ }^{23}$ Although the drug is effective for most patients, about $8 \%$ of trichomonad vaginitis patients are refractory to treatment. ${ }^{34}$ Trichomonad resistance to nitroimidazoles has been reported in various areas of the world and appears to be increasing. ${ }^{2}$

Some nitroimidazoles such as tinidazole, ornidazole are available in other countries. Even though alternative drugs may have longer half-lives, they are not clinically superior to metronidazole. Extended courses of topical treatments of clotrimazole, aminacrime, and sulfonamides have been evaluated in patients for whom a nitroimidazole was either contraindicated or unavailable. These treatments have been effective in less than $30 \%$ of the patients. ${ }^{3}$

Most treatment failures are produced by $T$ vaginalis isolates with a low susceptibility to metronidazole. These isolates are resistant to the drug both in vivo and under aerobic and anaerobic conditions in vitro. Inadequate susceptibility corresponds to a high minimum lethal concentration (MLC) of drug. The MLC is defined as the minimum lethal concentration of drug in which no motile organisms are visible after $48 \mathrm{~h}$ incubation at $37^{\circ} \mathrm{C} .^{5}$ These findings are confirmed by subculturing the trichomonads in a drug free medium. ${ }^{2}$

This current study employed the InPouch $\mathrm{TV}^{\mathrm{TM}}$ (pouch) test containing $4 \mathrm{ml}$ of culture medium to evaluate metronidazole MLCs for clinical isolates of $T$ vaginalis. Isolates were obtained from patients who had responded to treatment $(n=11)$. Isolates from patients $(n=5)$ who remained symptomatic after treatment with $250 \mathrm{mg}$ of oral metronidazole, tid for 7 consecutive days, were considered resistant.

\section{Materials and methods}

Before beginning the drug susceptibility tests, experiments were conducted to determine the effect of glacial acetic acid (GAA) on the growth of $T$ vaginalis. GAA was selected because it was recommended as the best solvent for metronidazole (personal communication, Sigma Chemical Company, St Louis, Missouri). Viability studies were performed in the pouch using 10 isolates of $T$ vaginalis in their logarithmic growth phase. Each was inoculated into a pouch containing $0.1 \mathrm{ml}$ of 
Table 1 Concentrations of $T$ vaginalis in the InPouch $T V$ test containing different concentrations ( $m M$ ) of $G A A\left(37^{\circ} \mathrm{C}\right)$

\begin{tabular}{|c|c|c|c|c|c|c|c|c|c|c|}
\hline \multirow[b]{2}{*}{ Conc of $G A A$ (mM) } & \multicolumn{10}{|c|}{ Numbers of $T$ vaginalis isolates } \\
\hline & 103 & 6 & 2 & 123 & 157 & 159 & 162 & 163 & 165 & 66 \\
\hline $\begin{array}{l}\left(1 \times 10^{4} \text { cells/ml, } 24 \mathrm{~h}\right) \\
\text { Control } \\
0 \cdot 4 \\
0 \cdot 8 \\
1 \cdot 6 \\
3 \cdot 2 \\
6 \cdot 5 \\
13 \cdot 1 \\
26 \cdot 2^{\star}\end{array}$ & $\begin{array}{l}24 \cdot 0 \\
32 \cdot 0 \\
32 \cdot 5 \\
32 \cdot 0 \\
28 \cdot 1 \\
2 \cdot 40 \\
0 \cdot 75 \\
-\end{array}$ & $\begin{array}{l}25 \cdot 2 \\
28 \cdot 0 \\
25 \cdot 4 \\
25 \cdot 0 \\
26 \cdot 0 \\
2 \cdot 37 \\
-\end{array}$ & $\begin{array}{l}30 \cdot 7 \\
31 \cdot 5 \\
31 \cdot 1 \\
29 \cdot 5 \\
30 \cdot 3 \\
2 \cdot 01 \\
0.55 \\
-\end{array}$ & $\begin{array}{l}25 \cdot 7 \\
26 \cdot 3 \\
24 \cdot 7 \\
25 \cdot 5 \\
24 \cdot 0 \\
1 \cdot 95 \\
-\end{array}$ & $\begin{array}{c}36 \cdot 2 \\
37 \cdot 0 \\
35 \cdot 8 \\
36 \cdot 7 \\
35 \cdot 0 \\
3 \cdot 01 \\
0 \cdot 80 \\
-\end{array}$ & $\begin{array}{l}32 \cdot 8 \\
34 \cdot 0 \\
31 \cdot 5 \\
33 \cdot 0 \\
32 \cdot 5 \\
3 \cdot 20 \\
0 \cdot 40 \\
-\end{array}$ & $\begin{array}{l}49 \cdot 7 \\
48 \cdot 0 \\
49 \cdot 5 \\
47 \cdot 8 \\
48 \cdot 7 \\
3 \cdot 90 \\
0 \cdot 68 \\
-\end{array}$ & $\begin{array}{l}52 \cdot 3 \\
51 \cdot 5 \\
52 \cdot 5 \\
49 \cdot 5 \\
50 \cdot 1 \\
4 \cdot 21 \\
0 \cdot 45 \\
-\end{array}$ & $\begin{array}{l}54 \cdot 4 \\
54 \cdot 5 \\
50 \cdot 3 \\
56 \cdot 2 \\
53 \cdot 7 \\
4 \cdot 37 \\
-\end{array}$ & $\begin{array}{l}41 \cdot 2 \\
39 \cdot 5 \\
40 \cdot 0 \\
41 \cdot 5 \\
38 \cdot 5 \\
3 \cdot 07 \\
0 \cdot 66 \\
-\end{array}$ \\
\hline $\begin{array}{l}\left(1 \times 10^{5} \text { cells } / \mathrm{ml}, 48 \mathrm{~h}\right) \\
\text { Control } \\
0 \cdot 4 \\
0 \cdot 8 \\
1 \cdot 6 \\
3 \cdot 2 \\
6 \cdot 5 \\
13 \cdot 1 \\
26 \cdot 2^{\star}\end{array}$ & $\begin{array}{l}87 \cdot 0 \\
95 \cdot 0 \\
85 \cdot 0 \\
97 \cdot 0 \\
86 \cdot 0 \\
3 \cdot 00 \\
0 \cdot 03 \\
-\end{array}$ & $\begin{array}{l}81 \cdot 0 \\
82 \cdot 1 \\
79 \cdot 1 \\
80 \cdot 5 \\
79 \cdot 5 \\
2 \cdot 90 \\
-\end{array}$ & $\begin{array}{c}81 \cdot 5 \\
80 \cdot 1 \\
79 \cdot 8 \\
78 \cdot 5 \\
82 \cdot 5 \\
2 \cdot 70 \\
0 \cdot 04 \\
\end{array}$ & $\begin{array}{l}80 \cdot 5 \\
79 \cdot 5 \\
80 \cdot 0 \\
80 \cdot 1 \\
78 \cdot 7 \\
2 \cdot 45 \\
-\end{array}$ & $\begin{array}{l}95 \cdot 0 \\
97 \cdot 7 \\
94 \cdot 8 \\
95 \cdot 3 \\
96 \cdot 7 \\
4 \cdot 01 \\
0 \cdot 07 \\
-\end{array}$ & $\begin{array}{l}94 \cdot 9 \\
95 \cdot 9 \\
93 \cdot 8 \\
97 \cdot 3 \\
94 \cdot 5 \\
3 \cdot 87 \\
0 \cdot 02 \\
-\end{array}$ & $\begin{array}{l}92 \cdot 2 \\
91 \cdot 0 \\
91 \cdot 7 \\
92 \cdot 7 \\
90 \cdot 5 \\
4 \cdot 21 \\
0 \cdot 03 \\
-\end{array}$ & $\begin{array}{c}96 \cdot 8 \\
97 \cdot 2 \\
93 \cdot 9 \\
95 \cdot 7 \\
98 \cdot 8 \\
4 \cdot 37 \\
0 \cdot 03 \\
-\end{array}$ & $\begin{array}{l}95 \cdot 5 \\
95 \cdot 8 \\
97 \cdot 2 \\
94 \cdot 7 \\
93 \cdot 2 \\
4 \cdot 07 \\
-\end{array}$ & $\begin{array}{l}90 \cdot 5 \\
91 \cdot 3 \\
91 \cdot 5 \\
89 \cdot 7 \\
90 \cdot 0 \\
5 \cdot 00 \\
0.03 \\
-\end{array}$ \\
\hline $\begin{array}{l}\left(1 \times 10^{6} \text { cells/ml, } 72 \mathrm{~h}\right) \\
\text { Control } \\
0 \cdot 4 \\
0 \cdot 8 \\
1 \cdot 6 \\
3 \cdot 2 \\
6 \cdot 5 \\
13 \cdot 1 \\
26 \cdot 2^{\star}\end{array}$ & $\begin{array}{l}26 \cdot 6 \\
27 \cdot 6 \\
26 \cdot 6 \\
23 \cdot 0 \\
27 \cdot 9 \\
9 \cdot 46 \\
-\end{array}$ & $\begin{array}{l}26 \cdot 1 \\
27 \cdot 0 \\
24 \cdot 7 \\
26 \cdot 7 \\
25 \cdot 6 \\
9 \cdot 05 \\
-\end{array}$ & $\begin{array}{l}26 \cdot 5 \\
28 \cdot 1 \\
24 \cdot 3 \\
23 \cdot 7 \\
24 \cdot 2 \\
9 \cdot 21 \\
-\end{array}$ & $\begin{array}{l}25 \cdot 6 \\
26 \cdot 8 \\
24 \cdot 7 \\
25 \cdot 0 \\
26 \cdot 2 \\
9 \cdot 00 \\
-\end{array}$ & $\begin{array}{l}39 \cdot 1 \\
40 \cdot 0 \\
36 \cdot 7 \\
38 \cdot 5 \\
37 \cdot 8 \\
9 \cdot 85 \\
-\end{array}$ & $\begin{array}{l}41 \cdot 5 \\
42 \cdot 3 \\
39 \cdot 9 \\
42 \cdot 5 \\
40 \cdot 1 \\
8 \cdot 67 \\
-\end{array}$ & $\begin{array}{l}38 \cdot 7 \\
38 \cdot 2 \\
37 \cdot 5 \\
39 \cdot 0 \\
38 \cdot 5 \\
9 \cdot 00 \\
-\end{array}$ & $\begin{array}{l}50 \cdot 8 \\
51 \cdot 5 \\
48 \cdot 7 \\
49 \cdot 5 \\
50 \cdot 5 \\
9 \cdot 01 \\
-\end{array}$ & $\begin{array}{l}49 \cdot 6 \\
48 \cdot 5 \\
50 \cdot 0 \\
47 \cdot 7 \\
49 \cdot 7 \\
8 \cdot 95 \\
-\end{array}$ & $\begin{array}{c}\mathbf{5 5 \cdot 7} \\
\mathbf{5 4 \cdot 7} \\
\mathbf{5 7} \cdot 0 \\
\mathbf{5 3 \cdot 5} \\
\mathbf{5 6 \cdot 6} \\
\mathbf{9} \cdot 15 \\
- \\
-\end{array}$ \\
\hline
\end{tabular}

-: No viable organisms

*: Four ml of media were mixed with $0.1 \mathrm{ml}$ of GAA $(17.4 \mathrm{M})$ to yield $420 \mathrm{mM}$ HOAc in the most concentrated preparation. Ten less concentrated stock solutions of GAA were prepared from the $17 \cdot 4 \mathrm{M}$ HOAc by two fold serial dilutions into NS, that is, maximum of $1: 512$. Four $\mathrm{ml}$ of media was mixed with $0.1 \mathrm{ml}$ of each of the diluted stock solution to obtain the listed concentration. Dilutions from $420 \mathrm{mM}$ to $26 \cdot 2$ were negative for all isolates and not listed in this table.

NS (normal saline) as a control and into additional pouches with different $0.1 \mathrm{ml}$ dilutions of GAA. The final concentrations of trichomonads were $1 \times 10^{4} / \mathrm{ml}, 1 \times 10^{5} / \mathrm{ml}$, and $1 \times 10^{6} / \mathrm{ml}$. After incubation at $37^{\circ} \mathrm{C}$ for $24 \mathrm{~h}$,
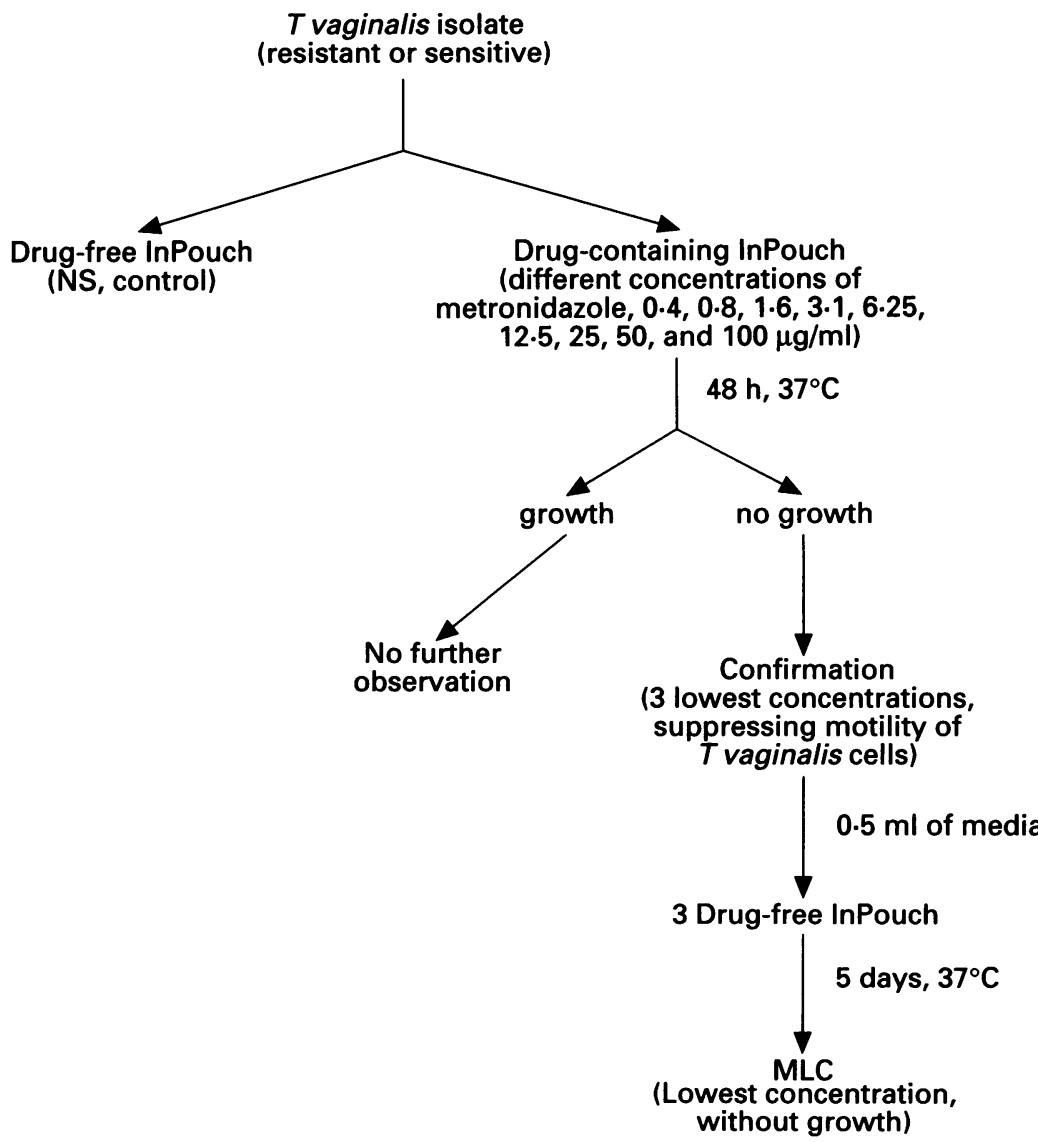

Figure 1 Flowchart of MLC determination. (The lowest concentration with no growth at the fifth day represents the $M L C$ ).
$48 \mathrm{~h}$ and $72 \mathrm{~h}$, the organisms were counted employing a haemacytometer. The density of organisms (cells $/ \mathrm{ml}$ ) for each pouch was calculated and the results compared by the paired $t$ test (table 1).

For MLC determinations both clinically resistant and sensitive motile isolates from the logarithmic growth phase $\left(37^{\circ} \mathrm{C}, 48 \mathrm{~h}\right)$ were used as inocula (final dilution of $1 \times 10^{5} / \mathrm{ml}$ ). Two-fold serial dilutions of metronidazole ranged from $50 \mu \mathrm{g} / \mathrm{ml}$ to $0.4 \mu \mathrm{g} / \mathrm{ml}$. Each $T$ vaginalis isolate was cultured in a pouch without metronidazole as a control, and in pouches containing different final concentrations of metronidazole. The tests were incubated at $37^{\circ} \mathrm{C}$ and the organisms were observed at $48 \mathrm{~h}$ to determine the MLC. To confirm the findings, $0.5 \mathrm{ml}$ of the 3 media with the least concentrated drug which suppressed motility, were subcultured in a pouch without metronidazole and incubated at $37^{\circ} \mathrm{C}$ for 5 days (fig $\mathbf{1}$ ).

To determine the effect of metronidazole on the viability of trichomonads, one clinically sensitive isolate (SJCR 66) and a resistant isolate $(K P)$ were each cultured in a pouch without metronidazole (containing NS as a control) and in pouches containing 12.50 $\mu \mathrm{g} / \mathrm{ml}, \quad 25.00 \mu \mathrm{g} / \mathrm{ml}$, and $37.50 \mu \mathrm{g} / \mathrm{ml}$ of metronidazole. After exposure to metronidazole, each culture was observed microscopically at $100 \times$. A haemacytometer was used to count viable organisms at $15 \mathrm{~min}, 30 \mathrm{~min}, 1$ h, $2 \mathrm{~h}, 4 \mathrm{~h}, 8 \mathrm{~h}, 12 \mathrm{~h}, 24 \mathrm{~h}, 48 \mathrm{~h}$ and $72 \mathrm{~h}$. The percentage of viable organisms (PVO) was determined as follows: percent viable organisms $=100 \% \times$ (viable cell count/total cell count). The relationships were evaluated between the concentration of metronidazole, the PVO and exposure times. 
Table 2 Comparison of the influence between normal control and different concentrations of $G A A$ on the growth of $T$ vaginalis $\left(37^{\circ} \mathrm{C}\right)$

\begin{tabular}{|c|c|c|c|c|}
\hline \multirow[b]{2}{*}{ Group } & \multicolumn{2}{|c|}{ Con of $T$ vaginalis (Cells/ml) } & \multirow[b]{2}{*}{ t Value* } & \multirow[b]{2}{*}{$p$ Value } \\
\hline & Mean & $S D$ & & \\
\hline \multicolumn{5}{|c|}{$(24 h)$} \\
\hline Control & $3.72 \times 105$ & $1.10 \times 105$ & - & - \\
\hline $0.4 \mathrm{mM} \mathrm{AA}$ & $3.82 \times 105$ & $9.42 \times 104$ & 0.2183 & $>0.50$ \\
\hline $0.8 \mathrm{mM} \mathrm{AA}$ & $3.73 \times 105$ & $9.80 \times 104$ & 0.0215 & $>0.50$ \\
\hline $1.6 \mathrm{mM} \mathrm{AA}$ & $3.77 \times 105$ & $1.01 \times 105$ & 0.1059 & $>0.50$ \\
\hline $3.2 \mathrm{mM} \mathrm{AA}$ & $3.67 \times 105$ & $1.01 \times 105$ & $0 \cdot 1059$ & $>0.50$ \\
\hline $6.5 \mathrm{mM} \mathrm{AA}$ & $3.05 \times 104$ & $8.37 \times 103$ & 9.7891 & $<0.0005$ \\
\hline $13.1 \mathrm{mM} \mathrm{AA}$ & $4.29 \times 103$ & $3.04 \times 103$ & $10 \cdot 5669$ & $<0.0005$ \\
\hline \multicolumn{5}{|c|}{$(48 h)$} \\
\hline Control & $8.95 \times 106$ & $6.17 \times 105$ & - & - \\
\hline $0.4 \mathrm{mM} \mathrm{AA}$ & $9.05 \times 106$ & $6.86 \times 105$ & $0 \cdot 3427$ & $>0.50$ \\
\hline $0.8 \mathrm{mM} \mathrm{AA}$ & $8.87 \times 106$ & $6.63 \times 105$ & 0.2793 & $>0.50$ \\
\hline $1.6 \mathrm{mM} \mathrm{AA}$ & $9.02 \times 106$ & $7 \cdot 16 \times 105$ & $0 \cdot 2342$ & $>0.50$ \\
\hline $3.2 \mathrm{mM} \mathrm{AA}$ & $8.90 \times 106$ & $6.74 \times 105$ & 0.1730 & $>0.50$ \\
\hline $6.5 \mathrm{mM} \mathrm{AA}$ & $3.66 \times 105$ & $7.96 \times 104$ & 43.6335 & $<0.0005$ \\
\hline $13.1 \mathrm{mM} \mathrm{AA}$ & $2.50 \times 103$ & $2.06 \times 103$ & $45 \cdot 8579$ & $<0.0005$ \\
\hline \multicolumn{5}{|c|}{$(72 h)$} \\
\hline Control & $3.80 \times 107$ & $1.09 \times 107$ & - & - \\
\hline $0.4 \mathrm{mM} \mathrm{AA}$ & $3.85 \times 107$ & $1.02 \times 107$ & $0 \cdot 1059$ & $>0.50$ \\
\hline $0.8 \mathrm{mM} \mathrm{AA}$ & $3.70 \times 107$ & $1.13 \times 107$ & 0.2014 & $>0.50$ \\
\hline $1.6 \mathrm{mM} \mathrm{AA}$ & $3.69 \times 107$ & $1.10 \times 107$ & 0.2246 & $>0.50$ \\
\hline $3.2 \mathrm{mM} \mathrm{AA}$ & $3.77 \times 107$ & $1.11 \times 107$ & 0.0610 & $>0.50$ \\
\hline $6.5 \mathrm{mM} \mathrm{AA}$ & $9.13 \times 106$ & $3.05 \times 106$ & 8.0659 & $<0.0005$ \\
\hline $13.1 \mathrm{mM} \mathrm{AA}$ & No viable org & & & \\
\hline
\end{tabular}

^Compared with control group.

Table 3 Comparison of MLC of metronidazole between clinically sensitive and resistant $T$ vaginalis isolates

\begin{tabular}{llll}
\hline Group & Number & Mean $(\mu \mathrm{g} / \mathrm{ml})$ & $S D(\mu \mathrm{g} / \mathrm{ml})$ \\
\hline Sensitive & 11 & 1.32 & 1.14 \\
Resistant & 5 & 15.00 & 8.48 \\
& $t=5.47$ & $\mathrm{p}<0.0005$ & \\
\hline
\end{tabular}

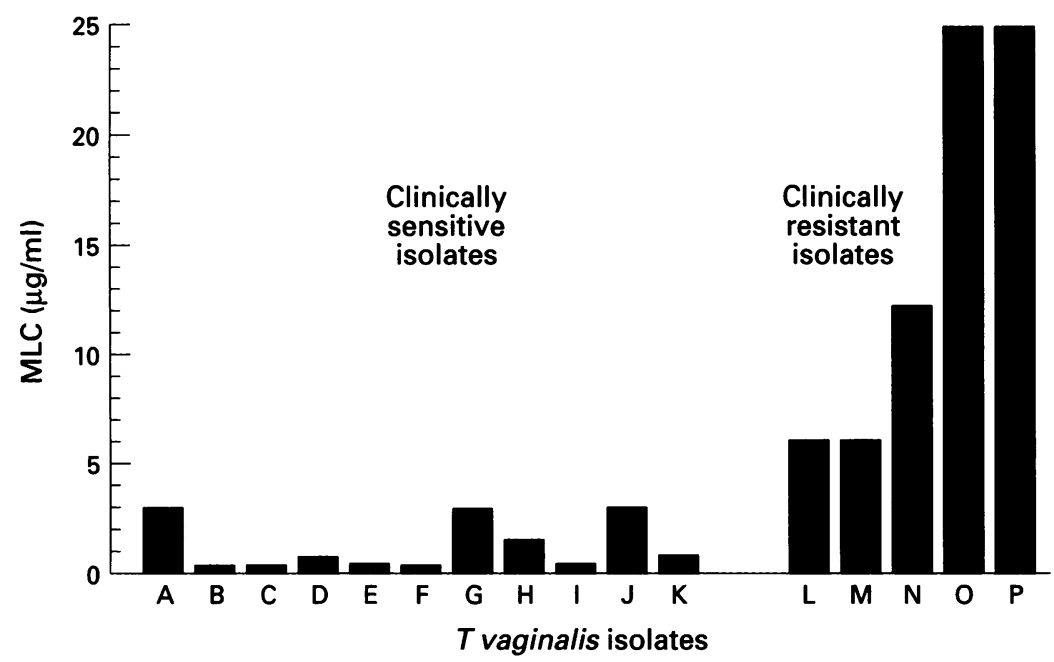

Figure 2 MLCs of metronidazole for $T$ vaginalis isolates.

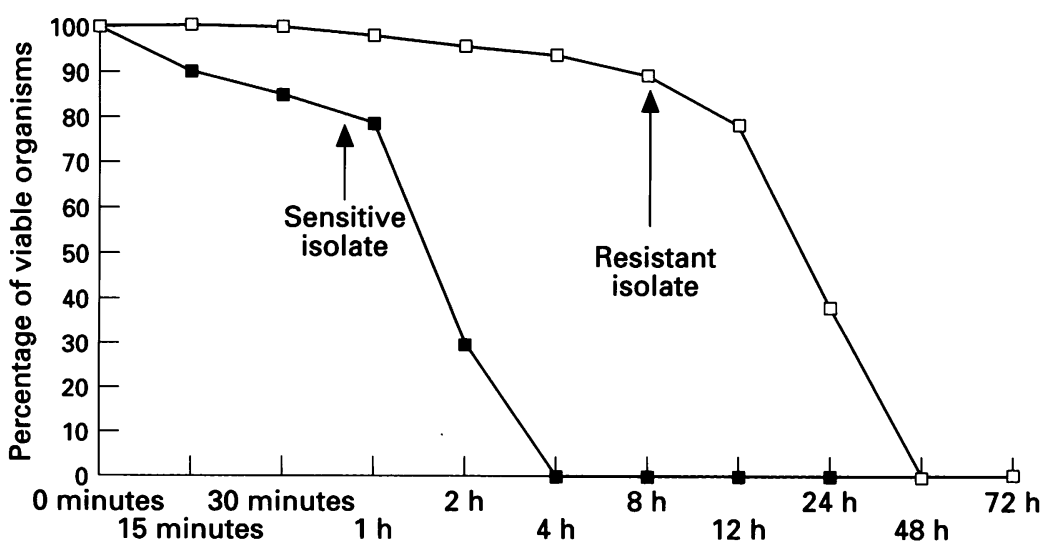

Time after exposure of $T$ vaginalis to metronidazole

Figure $3 T$ vaginalis viability after extended exposure to $12.5 \mu \mathrm{g} / \mathrm{ml}$ metronidazole.

\section{Results}

Tables 1-3 illustrate the effects of GAA on the growth of trichomonas. GAA at concentrations $>26 \cdot 2 \mathrm{mM}$ terminated $T$ vaginalis viability at $24 \mathrm{~h}, 48 \mathrm{~h}$, and $72 \mathrm{~h}$ (table 1 ). In 13.1 mM GAA no viable organisms were observed in 3 isolates $(6,123$, and 165 , at $24 \mathrm{~h}, 48 \mathrm{~h}$, and none were viable at $72 \mathrm{~h}$ (table 1 ). GAA had no significant effect on viability at concentrations of $<3.2 \mathrm{mM} \mathrm{GAA}$ ( $\mathrm{p}>0.50$, table 2 ). When the concentration of GAA was $<3 \cdot 2$ $\mathrm{mM}$ (that is, the $\mathrm{pH}$ of the medium was 8.5-8.6) the GAA did not inhibit the growth of $T$ vaginalis ( $p>0.50$ ) But GAA inhibited the growth of $T$ vaginalis at a concentration of $>6.5 \mathrm{mM}$ (that is, the $\mathrm{pH}$ of the medium was $<8.0$ ( $p<0.0005)$. These results indicate that GAA did not influence the growth of $T$ vaginalis in the pouch, but that $\mathrm{pH}<8.0$ inhibited growth. This suggested that the stock metronidazole should be dissolved with GAA and then diluted with NS to avoid the $\mathrm{pH}$ effect on growth in the pouches. In the current study the stock metronidazole solution $(100 \mathrm{mg} / \mathrm{ml})$ was prepared with GAA. After dilution with $\mathrm{NS}$, the concentration of GAA in the most concentrated metronidazole $(100 \mu \mathrm{g} / \mathrm{ml})$ solution used in the MLC determination was 0.42 mM HOAc. This was much less than the 6.5 $\mathrm{mM}$ which inhibited the growth of $T$ vaginalis in the pouch

The MLCs of clinically sensitive isolates were from $0.4 \mu \mathrm{g} / \mathrm{ml}$ to $3.1 \mu \mathrm{g} / \mathrm{ml}$ and that of clinically resistant isolates were between 6.25 $\mu \mathrm{g} / \mathrm{ml}$ and $25 \mu \mathrm{g} / \mathrm{ml}$ (fig 2). The mean MLC of clinically resistant isolates was about eleven fold higher than the mean MLC of clinically sensitive isolates. The difference was significant $(t=5 \cdot 47, \mathrm{p}<0.0005$, table 3$)$.

There were differences in the PVO for clinically sensitive and resistant $T$ vaginalis after exposure to $12.5 \mu \mathrm{g} / \mathrm{ml}, 25 \mu \mathrm{g} / \mathrm{ml}$, and 37.5 $\mu \mathrm{g} / \mathrm{ml}$ of metronidazole for as little as $15 \mathrm{~min}$. At $12.5 \mu \mathrm{g} / \mathrm{ml}$ the PVO of the clinically resistant isolate was $100 \%$ and that of the clinically sensitive isolate was $90 \%$ (fig 3). The PVOs of the clinically resistant isolate in the pouches containing $25 \mu \mathrm{g} / \mathrm{ml}$ and $37.5 \mu \mathrm{g} / \mathrm{ml}$ were $100 \%$ and $98 \%$ respectively. But the PVOs of the clinically sensitive isolate was either $90 \%$ or $87 \%$ (figs 4,5 ).

The PVO of the clinically sensitive isolate dramatically decreased after $2 \mathrm{~h}$ in $12.5 \mu \mathrm{g} / \mathrm{m}$ of metronidazole, by $1 \mathrm{~h}$ both in $25 \mu \mathrm{g} / \mathrm{ml}$ and $37.5 \mu \mathrm{g} / \mathrm{ml}$. The PVO of the clinically resistant isolate did not significantly decrease until after $8 \mathrm{~h}$ in $37.5 \mu \mathrm{g} / \mathrm{ml}$ metronidazole, or after $12 \mathrm{~h}$ in $12.5 \mu \mathrm{g} / \mathrm{ml}$ and $25 \mu \mathrm{g} / \mathrm{ml}$ (figs 3-5). This indicated that when the PVO of the clinical isolate did not decrease at $2 \mathrm{~h}$ in the pouch containing $>12.50 \mu \mathrm{g} / \mathrm{ml}$ of metronidazole, it could be resistant to metronidazole. Conversely, if the PVO of the clinical isolate decreased at $2 \mathrm{~h}$ in the pouch containing $>12.50 \mu \mathrm{g} / \mathrm{ml}$ of metronidazole, the isolate would be susceptible to metronidazole.

\section{Discussion}

Metronidazole treatment failures in patients 


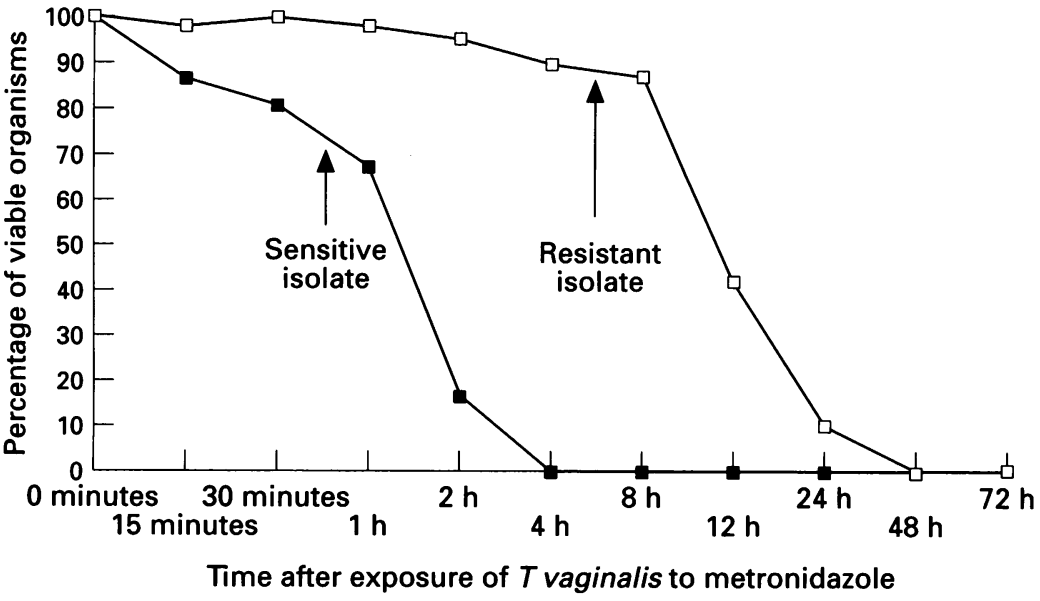

Figure $4 T$ vaginalis viability after extended exposure to $25 \mu \mathrm{g} / \mathrm{ml}$ metronidazole.

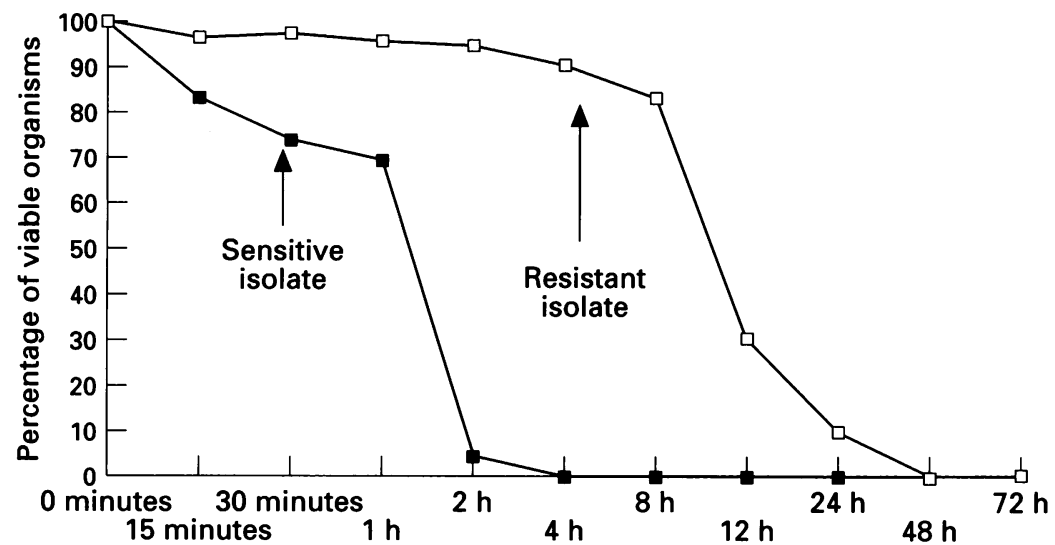

Time after exposure of $T$ vaginalis to metronidazole

Figure $5 T$ vaginalis viability after extended exposure to $37.5 \mu \mathrm{g} / \mathrm{ml}$ metronidazole.

have been attributed to non-compliance in taking the drug as prescribed, limited absorption from the gastro-intestinal tract, inadequate concentrations in the vagina, and degradation by vaginal microbial flora. ${ }^{67}$ In a study of 11 patients, who were repeated treatment failures to oral metronidazole, ( 3 dosage levels during a 14-17 day period), high pressure liquid chromatographic analyses indicated that even at the low dosages, metronidazole and its metabolite were present in the expected concentrations both in plasma and the vagina. ${ }^{8}$ Therefore, treatment failure of these patients was not due to any of the previously suggested causes. The current study confirmed the resistance of some isolates of $T$ vaginalis to metronidazole.

Metronidazole resistance has been evaluated employing a variety of procedures. A resistant trichomonas isolated from a patient with a recurrent infection was evaluated by a method employing both stoppered tubes and multi-well plates. ${ }^{9}$ This isolate only demonstrated resistance under aerobic conditions indicating the importance of the assay method. Another metronidazole study on resistant trichomonads used trichosel broth in tubes containing disks with various concentrations of metronidazole. ${ }^{10}$ After incubation either aerobically or anaerobically, the results indicated that anaerobic incubation significantly decreased the MIC of the resistant isolates to metronidazole.

Lossick et $a l^{11}$ reported that the anaerobic mean MLC of resistant isolates was about three-fold higher than that observed in nonresistant isolates $(5.0 \mu \mathrm{g} / \mathrm{ml}$ vs $1.6 \mu \mathrm{g} / \mathrm{ml})$. In the current study, the mean MLC of the clinically resistant isolates was about eleven fold higher than the mean of the clinically sensitive isolates $(15 \mu \mathrm{g} / \mathrm{ml}$ vs $1.3 \mu \mathrm{g} / \mathrm{ml})$. This difference was significant $(t=5 \cdot 47, \mathrm{p}<0.0005)$.

In this evaluation the InPouch $\mathrm{TV}^{\mathrm{TM}}$ test provided an improved environment for distinguishing between resistant and sensitive $T$ vaginalis. This suggests that the pouch test containing $3 \cdot 1 \mu \mathrm{g} / \mathrm{ml}$ metronidazole differentiates between trichomonads that are either sensitive or resistant. $T$ vaginalis remaining viable in pouches containing more than $3 \cdot 1 \mu \mathrm{g} / \mathrm{ml}$ of metronidazole would be considered resistant.

1 Roe FJ. Metronidazole: review of uses and toxicity. $\mathcal{f}$ Antimicrob Chemother 1977;3:205-12.

2 Lossick JG, Kent HL. Trichomoniasis: trends in diagnosis and management. Am 7 Obstet Gynecol 1991;165: 1217-22.

3 Markell EK, Voge $M$, John DT. Trichomonas vaginalis. In: Markell EK, Voge M, John DT, eds. Medical Parasitology, Philadelphia: WB Saunders Company, 7th Parasitology, Phil

4 Lossick JG. Therapy of urogenital trichomoniasis. In: Honingerly BM, ed. Trichomonads parasitic in humans, New York: Springer-Verlag 1st ed. 1989:324-41.

5 Yarlett NH, Yarlett NC. Activities of metronidazole and niridazole against Trichomonas vaginalis clinical isolates. $\mathscr{J}$ Antimicrob Chemother 1987;19:767-70.

6 Kane PO, McFadzean JA, Squires S. Absorption and excretion of metronidazole. Part II. Studies on primary failures. Br $\mathcal{F}$ Venereal $D$ is 1961;37:276-7.

7 Nicol CS, Evans AJ, McFadzean JA, Squires S. Inactivation of metronidazole. Lancet 1966;6:441.

8 Robertson DH, Heyworth R, Harrison C, Lumsden WH. Treatment failure in Trichomonas vaginalis infections in females. I. Concentrations of metronidazole in plasma and vaginal content during normal and high dosage. $f$ antimicrob Chemother 1988;21:373-8.

9 Meingassner JG, Thurner J. Strain of Trichomonas vaginalis resistant to metronidazole and other 5-nitroimidazoles. $\mathcal{f}$ Antimicrob Chemother 1978;15:254-7.

10 Smith RF, Di Domenico A. Measuring the in vitro susceptibility of Trichomonas vaginalis to metronidazole. Sex Transm Dis 1980:120-4.

11 Lossick JG, Muller M, Gorrell TE. In vitro drug susceptibility and doses of metronidazole required for cure in cases of refractory vaginal trichomoniasis. $\mathcal{F}$ Inf Dis 1986; 